\title{
Design and tactile perception: a case study on the finishes of the ceramic tile textures
}

\author{
Design e percepção tátil: um estudo a respeito dos acabamentos e \\ texturas do produto cerâmico de revestimento
}

\author{
Maico Carlos Vieira ${ }^{1}$ (1) \\ ${ }^{1}$ Universidade Federal de Santa Catarina - UFSC, Centro de Comunicação e Expressão, Programa de Pós- \\ graduação em Design - pós-Design UFSC, Campus Universitário Reitor João David Ferreira Lima - Trindade, \\ Florianópolis, SC, Brasil. E-mail: maicocarlosvieira@gmail.com.
}

How to cite: Vieira, M. C. (2021). Design and tactile perception: a case study on the finishes of the ceramic tile textures. Gestão \& Produção, 28(1), e5013. https://doi.org/10.1590/1806-

9649.2020v28e5013

\begin{abstract}
The object's surface has a great influence on the sensorial perception of the users, transmitting symbols and characteristics that can be interpreted by the users in a cognitive way. Design can attribute sensorial characteristics to the object's surface, however, few studies exist about how the users perceive the object's surface. This study aims to investigate the user's tactile perception, aiming at understanding the most relevant and attractive physical and aesthetic characteristics of the ceramic tile product through the eye tracking tool. The covering ceramic has a versatile characteristic that says respect textures, forms and finishes, being very useful in research regarding the users' tactile perceptions. This work is characterized as a case study, we conducted a study on 5 (five) individuals (professionals in architecture), in a show room of a company well regarded in the area of ceramic tile. The results obtained by this study can help surface designers, to understand the users' perceptions, so that they can have valid instruments in the understanding of the concepts related to perception, for the development of new products.

Keywords: Design; Tactile perception; Ceramic tile.

Resumo: A superfície de um objeto possui uma grande influência sobre a percepção sensorial do usuário, transmitindo características técnicas e estéticas que podem ser interpretadas pelos usuários de maneira cognitiva. $O$ design pode atribuir características sensoriais à superfície dos objetos, porém existem poucos estudos sobre como os usuários percebem as superfícies dos objetos. Neste contexto, este estudo teve como objetivo avaliar a percepção tátil do usuário, visando a compreensão das características físicas e estéticas mais relevantes e atrativas do produto cerâmico de revestimento por meio da ferramenta de rastreamento ocular eye tracking. A cerâmica de revestimento possui características versáteis no que diz respeito a suas texturas, formas e acabamentos, sendo muito útil para pesquisas a respeito das percepções táteis dos usuários. Esse trabalho se caracteriza como um estudo de caso, desta maneira foi realizado um estudo em 5 (cinco) indivíduos (profissionais arquitetura), em um show rom de uma empresa altamente conceituada no setor de revestimento cerâmico. Os resultados alcançados por este estudo podem auxiliar profissionais do setor de revestimentos, a compreender as percepções dos usuários, de modo que possam ter instrumentos válidos na compreensão dos conceitos relacionados a percepção do usuário, para o desenvolvimento de novos produtos.
\end{abstract}


Palavras-chave: Design; Percepção tátil; Cerâmica de revestimento.

\section{Introduction}

The texture can be considered a feature of physical artifacts, what can be perceived by the tactile sense and sometimes by the visual sense.

Referring to the cognitive character of the user's perception, the texture can be determinant in communication and experience that the user may have with an object.

The texture can also be considered a characteristic within the process of the development of new products, being able to present several functions, among them: durability, cleaning, impermeability, finishing, thermal and acoustic insulation, fire safety, hygiene, aesthetics, etc.

Design can assign expressive perceptual characteristics to the object's surface concrete, or virtually, by the organization of their appearance, mainly through visual, tactile and relief textures, with the purpose of reinforcing or minimizing the sensorial and cognitive interactions between the object and users.

To communicate cognitively with these characteristics, the designer must understand how aspects of the finishes of these surfaces interact with the user's perception.

Niemeyer (2006) writes that in comparison with the research around the visual stimuli, there are few studies on other modalities of the senses and also on how users perceive the products and the meanings they are attributed.

Munari (1998) also affirms that many designers still design only for the visual sense. They only produce something beautiful to look at and they don't care that the resulting object is unpleasant to the touch, if there isn't a formal relation with the human anatomy.

These concepts support that only visual perception isn't enough for the information and characteristics contained in a product or surface to be adequately understood by the user.

Designers and professionals of the area of product development must make good use of this gap and contribute, so that people use its diverse sensory capacities more frequently.

The ceramic tile has versatile features with regard to their textures, shapes and finishes, being very useful for research regarding the tactile perceptions of the user.

In this context, the objective of this study was to evaluate the user's tactile perception, aiming at understanding the most relevant and attractive physical and aesthetic characteristics of the ceramic tile product, through the evaluation of user perception using the eye tracking tool.

For this, the research was developed in 3 (three) steps:

1. Theoretical background: approaching topics related to ceramic tile, design and user perception;

2. Case study - tactile perception: where research was carried through in one show room of a company highly appraised in the ceramic tile sector. This phase aimed to evaluate the tactile perception of the participants (professionals in architecture), considering the characteristics and finishes of the ceramic tiles through the eye tracking equipment, counting on the participation of 5 (five) individuals;

3. Analysis and interpretation of data: this step aimed to present and to interpret the information that was collected in the case study of the eye tracing. 
Eye tracking is a viable method of analysis, used for decades to study human behavior.

Parallel to the eye tracking tool, video records were made and activities of each participant, allowed to identify the amount of times the volunteers touched the ceramic tile, and also to calculate the time the volunteer kept their hands in contact with the ceramic tile product.

This study intends to contribute a better knowledge regarding certain technical and aesthetic characteristics of ceramic tile products with a focus on the user's tactile perception.

\section{Design and perception}

Design both in its aesthetic character as its functional features and usability, are extremely related to the user's perception of the desired objects.

Design as a significant agent in translating an intention in a physical form or tool. In this context, it can be said that design is concerned with shape and form, being the result of a planned action with previous objects and the attribution of a sign (Schoernardie, 2013).

The design has the ability to align tangible and intangible aspects, such as brand and physical product; the needs of users and the attributes of the product, value and cost; technology and human factor; ergonomics and production; ergonomics and use of products, materials and perceptions (Martins \& Merino, 2011).

According to Maillet et al. (2006) the products have symbolic, aesthetic and functional abilities. That is: visual, sonorous, olfactory, tactile and taste stimuli are invitations to appreciation, associations and readings.

As Forlizzi et al. (2003) wrote, the process ends up being conducted experimentally and the designers lack a greater understanding of how to apply sensorial characteristics within the design of new products. The authors agree that the designer can not derive design specific responses to these sensory stimuli from a product design, but rather can provide contexts that lead to a desired sensory experience.

Bürdek (2006) states that design needs to express the particularities of each product through its own configuration; it should make visible the function of the product, its handling, to provide a clear reading of the user; should make transparent the most current state of technical development; you should not just stick to the product itself.

One of the objectives of design is to create high levels of satisfaction and to increase the profits in ventures from the union of the mix design: performance, quality, durability, appearance and costs (Domingues, 2011).

[...] the reactions to an object produced by design are three different species and reciprocally influential, so much so that it is not possible to take them into separate and independent consideration, despite the fact that one of them is subjective and the others have an objective character, or at least so be considered by the observer (Tedeschi, 1968).

For Baxter (1999), when an observer says that a product resembles something, it is meaning what he thinks of the product thus, the image can convey the symbolism of a certain product.

According to Kunzler (2003), sensorial evaluation is a suitable way to catalog user perceptions regarding the characteristics and functions of a product. 
Meira (2005) states that companies that really understand how users will react to different product characteristics will have a big advantage over others.

The identification and categorization of sensory factors facilitate the next phase of how they can be integrated into product design. In this context, a consensus about these theories becomes evident: the user is the object and objective of this process. And it is through their perception that artifacts are produced with a symbolic and sensorial character.

In the context of this research, the study and contextualization of these terms correlated to the user's perception, more specifically the tactile perception, that is, perceptions established by the interaction of the surface of the objects, perceived by the touch of the hands becomes relevant.

\subsection{Tactile perception}

Klatzky (1998) correlates the term perception as synonymous with grasping, receiving, and taking in the hands. The concept is associated with touch and its movement, considered by the author, an action by contact to feel (by light, sound, odor and taste). In this sense, Gobé (2002) also says that touch is a literal way of getting hold of an object.

Kendel et al. (1997), affirm that among all the senses, the tactile perceptions are those that most involve the attention of the people. According to the authors this is because tactile perceptions are not direct records of the world, but rather are sensations built in accordance with the innate rules of each individual's nervous system.

The tactile stimulus has receptors that produce a discharge of action potentials in the adherent fibers of the hand. According to Legge et al. (2008), the tactile perception contains greater sensitivity in the identification of the stimuli.

According to Schimid (2005), touch is the meaning that allows the concrete interaction of people with the physical world, because it is not based on representations, such as contemplating an image, or hearing a recording.

Klatzky \& Lenderman (2009) point out touch as the first sense that develops in the human being, corresponding to the somatic sensorial system, composed by a variety of nerve endings distributed by the body in the processing of different stimuli.

Montagu (1988) states that the skin is multiple, hybrid of tessitures and contexts in different parts of the body the skin varies in texture, flexibility, color, odor, temperature, innervation and other aspects. The author says that an area covered by the surface of the skin has a huge number of sensory receptors capturing stimuli of heat, cold, touch, pressure and pain.

For Lacey et al. (2007), tactile perception meets the sensations in reaction to external stimuli and alteration of the environment. For the authors, these stimuli are characterized as: a) exteroceptive (provide information about the external environment) and; b) interoceptive or visceral (convey information about internal functions). According to the authors, there are four types of exteroceptive sensations, listed as: pain, thermal sensation (temperature), pressure and proportional sense.

The surfaces have a great influence on their sensory effect. The textures allow for combinations of different materials that are responsible for the associations of ideas and sensations of cleanliness, warmth, lightness, cold, freshness, softness, etc. (Plaza, 2003). 
One can affirm that the act of touch entails in a direct interaction with the surface. Thus, tactile perception allows the user to recognize the shape, size, temperature and texture of the surfaces in contact with the skin.

\subsection{Surface characteristics}

For Lacey et al. (2007), the surface presents in a two-dimensional space, but is perceived in the three-dimensional space with respect to its manipulation.

The surface characteristics can be considered independently of the object. The recognition of these characteristics facilitates the perception of the concept object.

According to Klatzky (1998) the attributes related to the surface are: temperature, hardness, texture and roughness.

- Temperature: corresponds to the sensation of heat to which it refers in the analysis of the rate of its transfer in a system. According to the author, the temperature distribution in an object is given by the combined effects in the modes of heat transfer (conduction, convection and radiation), and it is difficult to isolate the concept of temperature;

- Hardness: the hardness of the material occurs through the factors used in the material development, related to the strength and durability of the product. According to Klatzky (1998), these materials are classified in: ceramic, natural, composites, metals and polymers. Here again, it is necessary to highlight pottery, a relevant term in the development of this study;

- Texture: the texture of the surface promotes in tactile terms the roughness, adhesion, slippage or friction. This is characterized by its roughness (Klatzky, 1998);

- Roughness: it is the set of irregularities, that is, microparticles that make up the surface, reflecting the properties of the touched surface, with the interaction of the explored object. For Klatzky (1998), the roughness is the result of the process by which the product was obtained or a specific process for surface finishing.

Figure 1 below shows the tactile holdings of the object, according to the concepts of Lederman \& Klatzky (1987).

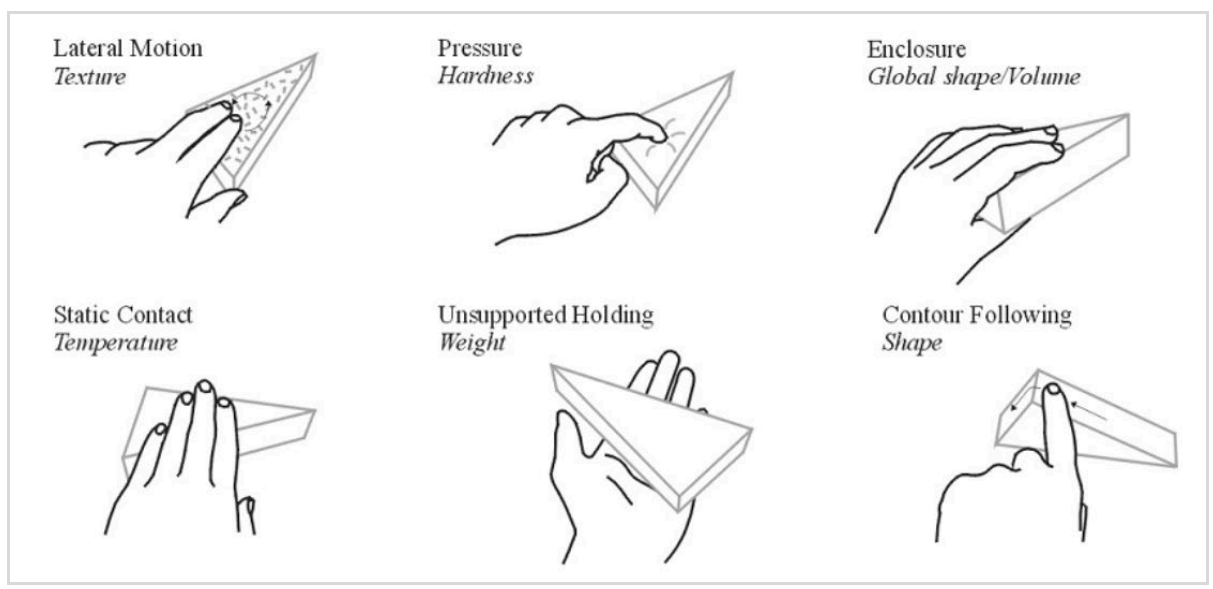

Figure 1. Explore tactile procedures (Lederman \& Klatzky, 1987). 
Loch (2008) also classifies the characteristics of the surfaces as: geometric, shape, size and volume. The author states that together with the graphical variables, these help in the recognition of information, as they depend on the cognitive actions derived from touch. For the author, these tactile graphical variables are divided into four elements in the process of information perception: texture, height, shape and symbol.

Finally, the tactile perception implies a direct contact with the surface to be explored, which makes it possible to feel the physical state of the objects, informing us about the solid, liquid or gaseous states, as well as superficial aspects (polished or rough, (dry or wet), shapes and dimensions, among other characteristics (Schimid, 2005).

The information absorbed by the touch is of great use, since such sensations received can arouse other feelings, since the textures have optical, thermal and tactile characteristics and, therefore, it brings with it cultural and symbolic values coming from its attributes.

\section{Ceramic tiles}

Currently, ceramic tiles are among the most commonly used surface tile products in construction. The versatility of textures, colors, images, shapes and finishes allow the use of ceramic tiles for various uses.

Companies in the ceramic industry generally have a specialized department for the development of new products, where they research market trends in construction, architecture and decoration, as well as new materials that perform a high technical and aesthetic quality in their products.

Thus, the design in the sector of ceramic tiles, designs products with a powerful decorative and aesthetic load. At the same time, these products have hygienic, waterproofing and durability functions.

The ceramic tile product serves to coat vertical and horizontal architectural elements, as well as contributing to the creation of spaces and environments for different uses and concepts.

With innumerable possibilities, due to the inherent decorative capacity of its surface and versatility of textures and formats, highlighting its use in architectural construction, the product has invaded the markets of other materials such as carpets, linoleum, concrete, wood and natural stone. Aligned with cutting-edge technology, market research and differentiated design, the naturalness of these tiles becomes increasingly noticeable.

In the context of the current research, it becomes relevant to understand some characteristics and classifications of the finishes of the ceramic tile product.

\subsection{Characteristics and finishes ceramic tiles}

Ceramic tiles are classified according to their properties. These properties are directly linked to the characteristics of the raw materials used for their manufacture.

Thus, six (6) types of finishes were most frequently used in the ceramic tile. The characteristics and differences between them are presented below. 


\subsection{Polished (PO)}

Ceramic tiles with this feature, receive a protective layer and polish after being produced, leaving the surface extremely smooth, providing a high standard of shine.

Figure 2 shows some environments that used ceramic tile with this finishing characteristic.
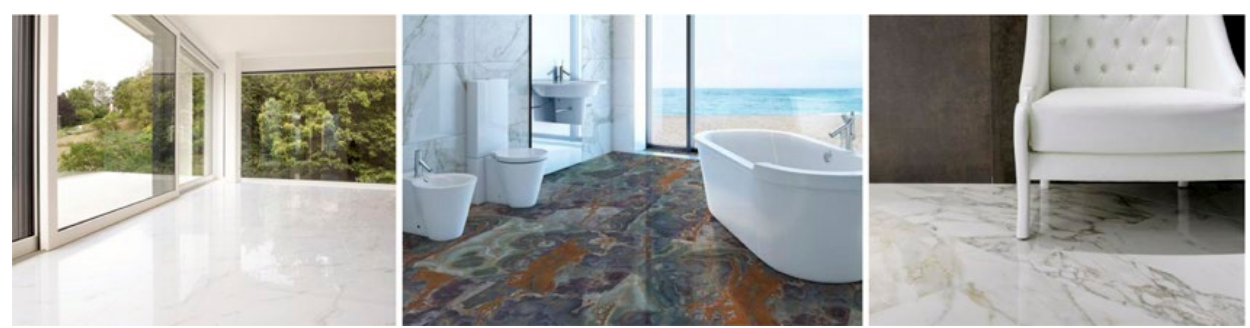

Figure 2. Polished ceramic tile. (Author collection, 2018).

A striking feature of this type of finish is the reflection of luminosity. This characteristic refers to a more sophisticated and broader environment.

\subsection{Shiny (SH)}

One of the most classic finishes of the ceramic tile, this finish also has a bright feature, but in this case, instead of polishing, a special enamel is added on the surface of the pieces.

The following (Figure 3) are some environments that used the shiny finish.
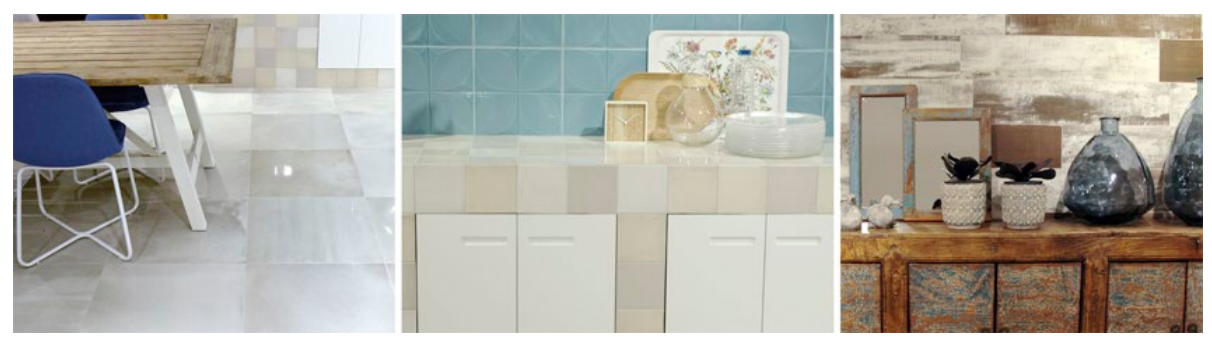

Figure 3. Shiny ceramic tile. (Author collection, 2018).

\subsection{Satin (SA)}

The surface of satin ceramic tiles has a light and discreet gloss, but the biggest characteristic of this type of finish is its soft and silky feeling, very pleasant and comfortable to the touch.

As can be seen (Figure 4), this type of ceramic surface also conveys the reality of other types of surfaces. 


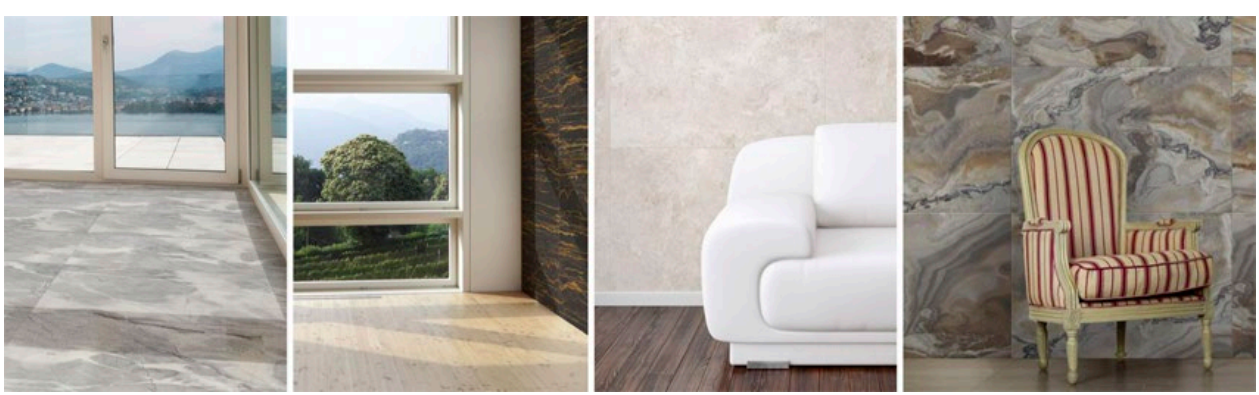

Figure 4. Satin ceramic tile. (Author collection, 2018).

\subsection{Matte (MA)}

The matte finish provides a completely frosted and drier effect on the surface of ceramic tiles. This finish transmits a great reality, reproducing textures very similar to wood, stones, cement, etc.

Figure 5 shows some environments that used ceramic tile with this finishing characteristic.
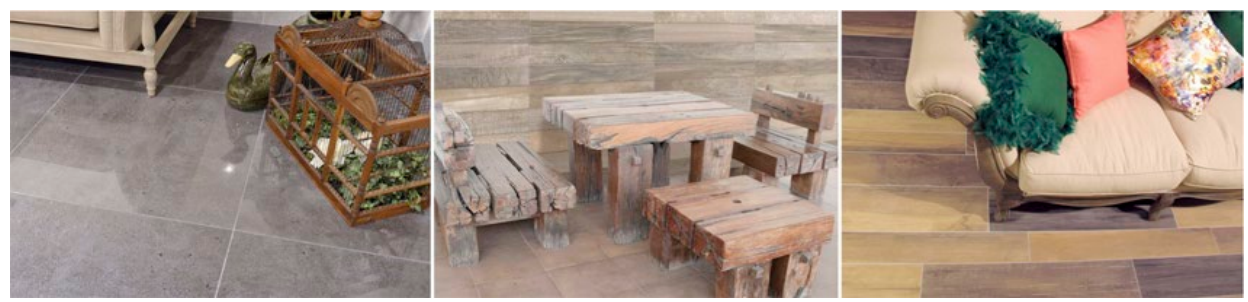

Figure 5. Matt ceramic tile. (Author collection, 2018).

\subsection{Natural (NA)}

Similar to matte texture, the natural finish has a matte surface, but slightly rougher, and can be compared to elements of nature such as marbles and woods, as can be seen in Figure 6 below.
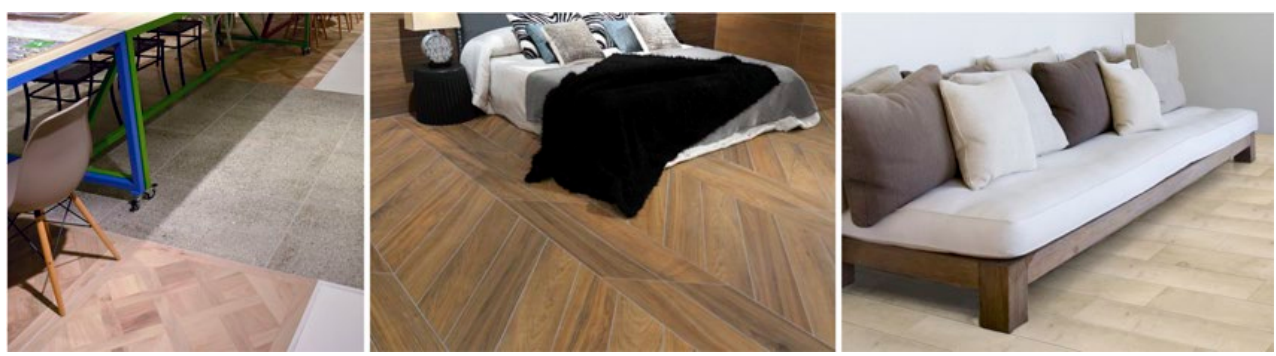

Figure 6. Natural ceramic tile. (Author collection, 2018). 
Slightly slippery, this finish is suitable for high-traffic areas such as airports, hospitals and shopping malls.

Products with these characteristics are also very pleasant to the touch and arouse a tactile curiosity due to their fidelity of transmitting textures of natural surfaces like wood and marble.

\subsection{Hard (EXT)}

Suitable to cover external areas such as sidewalks, ramps, patios, balconies and gardens, the ceramic tiles that have this feature minimize the risk of accidents in areas exposed to inclement weather.

As can be seen (Figure 7), this type of ceramic surface transmits the reality of tiles with more rustic characteristics.
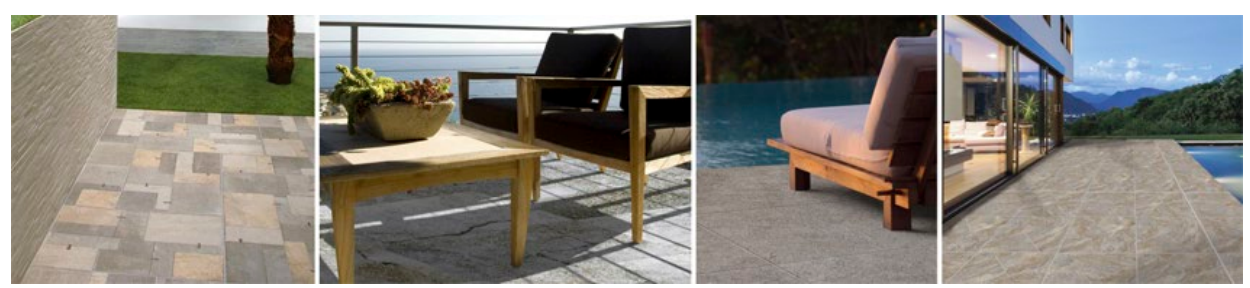

Figure 7. Rustic ceramic tile. (Author collection, 2018).

Because it has an abrasive surface, this finish is also recommended for areas that have frequent contact with water.

Still referring to the versatility of ceramic tile products, the same product can have more than one type of finish, color or shape, and can be used in environments with different needs only changing the surface finish and surface.

Such finishes go far beyond aesthetic quality and personal taste. The correct use of the ceramic tile provides safety for the environment and comfort for the user.

\section{Methodological procedures}

Considering the problem in question and in order to understand the theme of the design related to tactile user perception, this study has in its exploratory objective, the aim to provide greater understanding with the proposed problem.

In this context, the research is related to a case study, with the objective of deepening knowledge about a problem not sufficiently defined, aiming to stimulate understanding, suggest hypotheses and questions or develop theories (Mattar, 2001).

The case study comprises in analyzing one or more objects (cases) more deeply, to allow its ample and detailed knowledge.

According to Yin (2001) and Voss et al. (2002), the case studies can be classified as to their content and final objective. According to Yin (2001), the main trend of the case study is to try to clarify why a decision or a set of decisions were made, how they were implemented and with what results. 
This study is in line with these theories, as it aims to obtain a greater understanding and identification of the relevant physical and aesthetic characteristics of a ceramic tile product in the user 's perception, through tools and methods of analysis.

\subsection{Focus group}

According to Vergara et al. (2011), focus group use is particularly appropriate when the purpose is to explain how people consider an experience, idea or event, since discussion during events becomes effective in providing information about what people think or feel, or even how they act.

In this way, focus groups can serve a variety of purposes. According to Fern (2001) there are two categories of focus group: a) the first is aimed at asserting hypotheses and evaluating the theory; b) the second, consequently, is directed to the practical applications, that is, the use of concepts and theories in particular contexts.

In the perspective of this study, Veiga \& Gondim (2001) also classify the tool as a resource to understand the process of constructing the perceptions, attitudes and social representations of human groups.

According to Merton et al. (1990) focus groups are usually employed in exploratory or evaluative research - and may be the main source of data.

Tullis \& Albert (2008) argue that in any study of product and usability, the correct choice of the participants has a great impact on the conclusions and for this reason an adequate planning is essential to select the most representative ones as much as possible.

According to the authors there are no rules to state that the data will only be valid from an ' $x$ ' number of participants in a study. This number should be chosen based on two factors: the purpose of the study and the tolerance for a margin of error.

Faulkner (2003), based on a large number of studies, states that the number of 5 participants can reveal up to $85.55 \%$ of the problems, but does not condemn their use in product evaluation and usability, only makes clear to the evaluator the reliability of the data. The author represents in Table 1 below, a reference on the variability of the number of participants, with the percentage of discoveries of the product and usability problems that a study can achieve.

Table 1. Total Percentage of Product and Usability Issues.

\begin{tabular}{ccccc}
\hline $\mathbf{N} .{ }^{\circ}$ users & \% minimal & \% average & $\begin{array}{c}\text { Standard } \\
\text { Desviation }\end{array}$ & Standard Error \\
\hline 5 & 55 & 85.55 & 9.2957 & -9295 \\
\hline 10 & 82 & 94.686 & 3.2187 & -3218 \\
\hline 15 & 90 & 97.050 & 2.1207 & -2121 \\
\hline 20 & 95 & 98.4 & 1.608 & -1608 \\
\hline 30 & 97 & 99.0 & 1.1343 & -1464 \\
\hline 40 & 98 & 99.6 & 0.8141 & -1051 \\
\hline 50 & 98 & 100 & 0 & 0 \\
\hline
\end{tabular}

For this study, the focus group consisted of 5 (five) individuals that corresponded to an average of $85.55 \%$ reliability of studies in usability and user perception. Participants met the research criteria and were available for the area study. 
Considering that in recent years the ceramic tile consumer market is architecture oriented, and the end consumers are hiring the services of architects and designers to define which tiles will be selected to be seated in homes, establishments, environments, etc., has been defined as a target audience for this research by architectural professionals, designers and ceramic tile industry experts.

\subsection{Participating institution}

The research was developed together with a company of ceramic tiles in the state of Santa Catarina. The company has a network with approximately 150 (one hundred and fifty) stores located in all regions of Brazil, to strategically expose its products, assisting in distribution and sales throughout the country and abroad.

According to the company, the products marketed in the network are beyond exclusive, are innovative and anticipate market trends with design and quality.

It is noteworthy that the state of Santa Catarina has become a ceramic pole and is among the largest producers and suppliers of ceramic tile in the world. Like many companies in this region, such a participating institution has the design as an ally in the strategy for market positioning, promoting the research and innovation of knowledge in this segment.

\subsection{Eye tracking}

This step was aimed at collecting data to be analyzed. Initially the participants were taken to the show room of a ceramic tile company from southern Santa Catarina, containing a variety of exposed ceramic tiles.

Participants walked the environment making use of the eye tracking equipment, in this way the equipment can record the eye movement of each individual.

The equipment used in the research was the SMI Eye Tracking Glasses 2 wireless (SMI ETG 2W) (Figure 8), it was provided by the Design Management Center (NGD) and Design and Usability Laboratory (LDU) of the Federal University of Santa Catarina - UFSC.
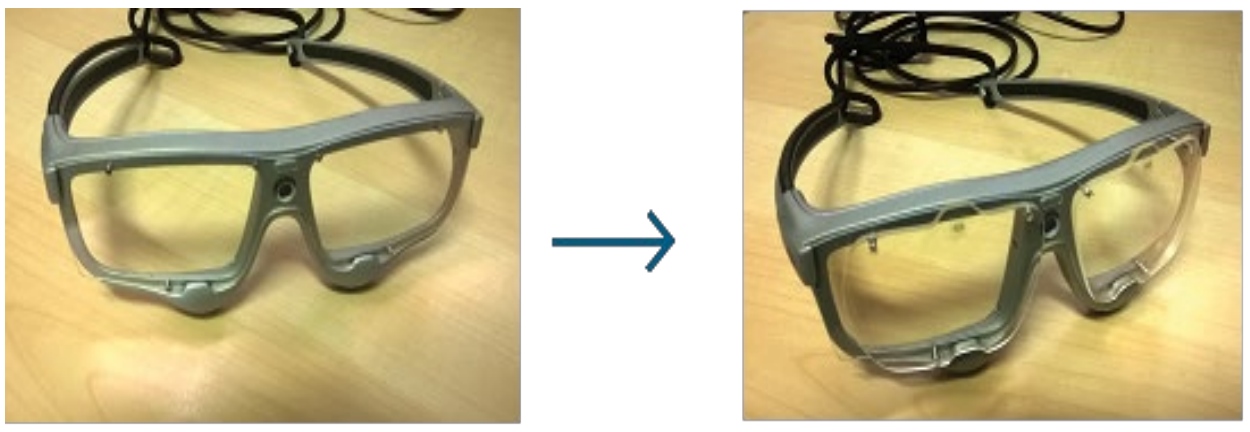

Figure 8. Eye tracking glasses.

Eye tracking is designed to capture the behavior of a person's natural look in real time.

The methodology applied in the study of ocular tracking using this equipment is very effective when used in perception and usability assessment techniques (Goldberg \& Kotval, 1999). 
Parallel to eye tracking using the eye tracking tool, video recordings of the course and activities of each participant were made, which allowed to identify the number of times the volunteer touched the pieces, as well as calculating the time in which the same kept his hands in contact with the ceramic tile product.

These data can be combined with other assessment methods to provide a better understanding of user-product interaction issues.

In the context of this study, the procedures were used to measure the time that each participant made the use of touch to evaluate the surface of the ceramic tile.

The process occurred as follows:

1. Initially, the participant received an explanation of the consent term applied to research in humans;

2. It was informed that the test would have an average term of 15 (fifteen) minutes, however, if it would require more time to perform the course and analysis of the tiles, it would be allowed;

3. The volunteer then placed the eye tracking and received the basic guidelines on the use of the equipment. The equipment requires the calibration of three points for each participant, in order to guarantee the safety of the results, and this lasted on average 30 (thirty) seconds;

4. After the calibration the subject had time to adjust to the equipment and feel comfortable to start the test and go through the showroom.

\subsection{Data analysis}

For this step all the data collected by the eye tracking equipment were analyzed, which were generated through the iView ETG - SMI BeGaze 3.6.52 data collection software.

In Figure 9, the interface and information generated by the software can be visualized.

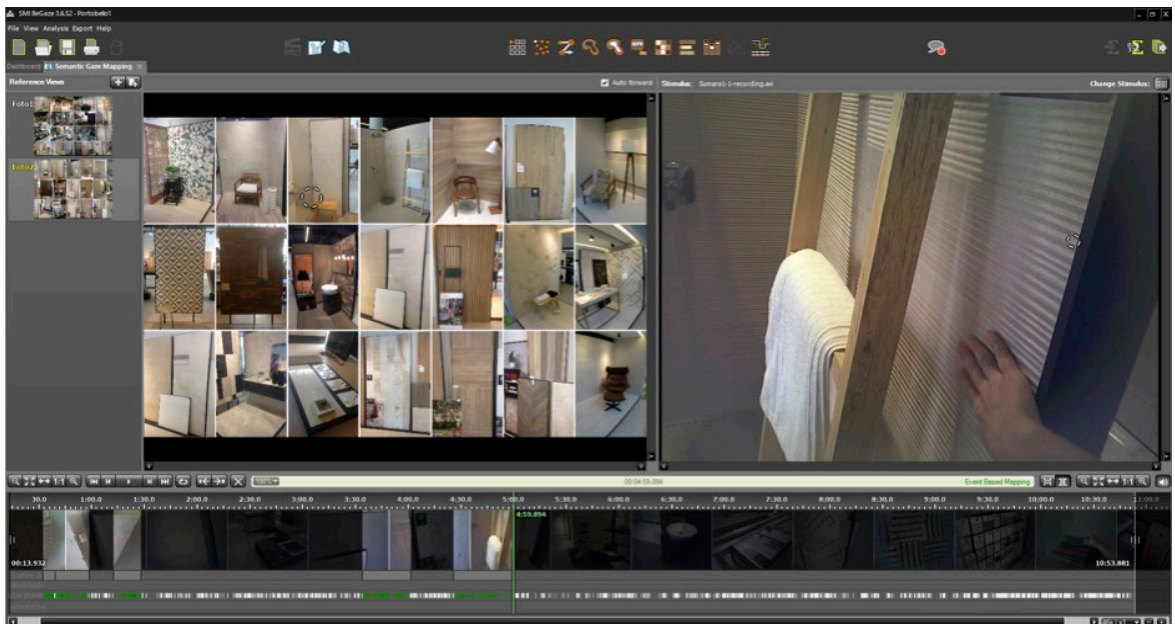

Figure 9. Software iView ETG - SMI BeGaze 3.6.52. 
It is worth noting that eye tracking equipment can provide other information such as sequence and counts of visual fixations, path traveled by the look, thermal map of the areas and interest, and video recording of the visual activities of each participant.

However, for the main purpose of this article, only the quantity and time information were used that each participant kept their hands in contact with the surface of the ceramic tile, where it was possible to measure the tactile perception of the participants.

\section{Case study analysis}

From the information generated by the eye tracking equipment and the video recordings made in this research, it was possible to analyze and measure the number of times the participant touched the pieces, as well as calculate the time in which the participants kept their hands in contact with the ceramic tile product.

Based on the collected information, it was noticed that the ceramic tile products that faithfully reproduce other types of surfaces such as wood, stones, cements, marbles, etc., aroused the tactile perception of the participants.

The accuracy of the textures with the natural finish (NA) represented $40.4 \%$ of the time the participants kept their hands in contact with the ceramic tiles (Table 2). Products that presented a satin finish (SA) accounted for $20.6 \%$, followed by matte finishing (MA), which accounted for $15.2 \%$ of the time in tactile contact.

Table 2. The comparison of characteristics of ceramic tiles.

\begin{tabular}{ccccc}
\hline Characteristic & Number of time $^{\mathbf{a}}$ & $\begin{array}{c}\text { Total Time } \\
(\mathbf{m m}: \mathbf{s s})^{\mathbf{b}}\end{array}$ & $\begin{array}{c}\text { Average } \\
(\mathbf{m m : s s})^{\mathbf{c}}\end{array}$ & $\begin{array}{c}\text { Percent } \\
\mathbf{( \% )}^{\mathbf{d}}\end{array}$ \\
\hline Polished & 11 & $00: 44$ & $00: 09$ & $5.5 \%$ \\
\hline Shiny & 18 & $01: 21$ & $00: 16$ & $10 \%$ \\
\hline Satin & 35 & $02: 46$ & $00: 32$ & $20.6 \%$ \\
\hline Matte & 25 & $02: 03$ & $00: 25$ & $15.2 \%$ \\
\hline Natural & 96 & $05: 26$ & $01: 05$ & $40.4 \%$ \\
\hline Hard & 16 & $01: 07$ & $00: 13$ & $8.3 \%$ \\
\hline Total & $\mathbf{2 0 1}$ & $\mathbf{1 3 : 2 7}$ & $\mathbf{0 2 : 4 1}$ & $\mathbf{1 0 0 \%}$ \\
\hline
\end{tabular}

a Number of time the participants touched the ceramic tile; ${ }^{b}$ Total time that the participants kept their hands in contact with ceramic tiles; ${ }^{c}$ Average time of contact the ceramic tiles; ${ }^{d}$ Percentage of the time the participant kept his or her hands in play in relation to the time of the course; e Sum of all the ceramic tile characteristics.

The finishes that had luster and a rougher texture, even presenting a certain naturalness in their products, did not awaken the tactile perception so considerably equal to the finishes that had softer and silky textures.

Products with shiny finish (SH) accounted for $10 \%$ of the time in tactile contact of participants. Polished surfaces (PO) that presented a high level of brightness, even with a pleasant texture to the touch, represented only $5.5 \%$ of the touch of the participants.

Rough and rustic textures that are presented in the hard finish (EXT) accounted for $8.3 \%$ of the time the participant kept their hands in contact with the piece. 
To better illustrate such data, Figure 10 shows the percentages of the finishes and characteristics of the ceramic tile product.

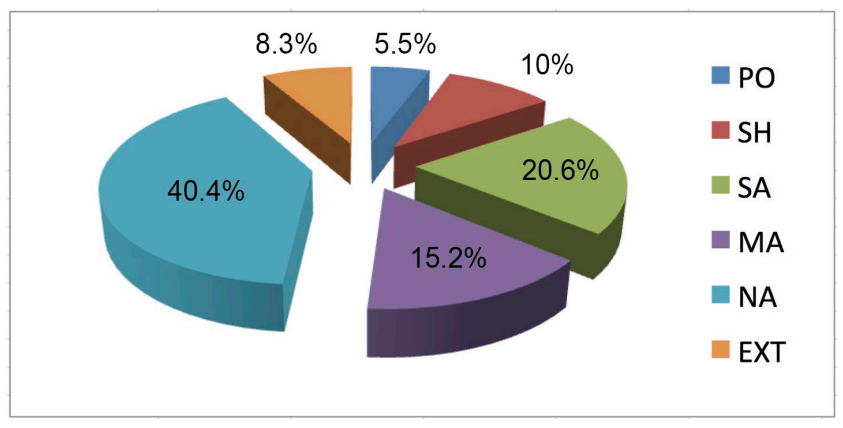

Figure 10. Tactile perception of ceramic tile finishes.

This phase had the objective of evaluating the tactile perception of the participants in face of the characteristics and finishes of the ceramic coverings through the eye tracking equipment.

\section{Concluding discussion}

Initially, the bibliographical research presented terms and concepts relevant to this work, but it was noticed that there are few studies relating cognition and tactile perception to the surface design and mainly to the ceramic tile design.

In comparison to the research on tactile stimuli, there was a lack of studies on other modalities of the senses and also on how users perceive the textures and finishes of the products and what meanings are attributed to them.

It can be said that there is a need for sensory improvement in saying that one has to feel the textures of life again, giving value to them as a condition to recover the beauty of the senses (Okamoto, 2002).

In this context, it becomes important to understand the aspects of user behavior by reading their sensations in the use of cognitive resources, which can be explored in the tactile perception.

The concepts studied point to design with the purpose of formalizing, that is, in its character of giving shape and meaning referring to cognitive and aesthetic issues, producing objects from the practical application of this scientific knowledge.

In this way, it is suggested practices of greater interdisciplinary between design management, cognition, and human perception.

It is also relevant to other areas of surface design, since many ceramic products are similar to other flooring products such as wood, laminate, marble and granite, stones, wallpaper, etc.

The successful application of tools such as eye tracking, along with the methodological procedures of this research, offers knowledge that can be used in various applications, such as the evaluation of other products and user behaviors.

It was noticed that the products that most represented with fidelity, natural products like wood, stones and marbles, aroused a greater curiosity of the tactile perception of the participants. Through the tactile perception of the participants, it can be concluded 
that the finishes of the ceramic surfaces that had natural texture stand out in comparison to the other finishes of the ceramic tile product.

This research has contributed to the area of development of new products since it defined some variables that relate to the tactile perception about the characteristics and finishes of the ceramic tile product and that can be used in other types of tile products.

Also in this context, the results achieved by this study can help professionals in the tile sector, to understand the user's perceptions, so that they can have valid instruments in the understanding of the user's way of thinking and perception, in the development of new products.

\section{References}

Baxter, M. (1999). Product design: practical guide to systematic methods of new product design and development. Cheltenham: Stanley Thornes.

Bürdek, B. (2006). History, theory and pratice of product design. São Paulo: Blücher.

Domingues, F. (2011). Design, cultura e semiótica: em direção a um modelo para análise das variáveis semântico-culturais (Dissertação de mestrado). Universidade do Estado de Minas Gerais, Belo Horizonte.

Faulkner, L. (2003). Beyond the five-user assumption: benefits of increased sample sizes in usability testing. Behavior Research Methods, Instruments, \& Computers, 35(3), 379-383. http://dx.doi.org/10.3758/BF03195514. PMid:14587545.

Fern, E. F. (2001). Advanced focus group research. California: Thousand Oaks. http://dx.doi.org/10.4135/9781412990028.

Forlizzi, J., Disalvo, C., \& Hanington, B. (2003). On the relationship between emotion, experience and the design of new products. The Design Journal, 6(2), 29-38. http://dx.doi.org/10.2752/146069203789355507.

Gobé, M. (2002). A emoção das marcas. Rio de Janeiro: Campus.

Goldberg, J. H., \& Kotval, X. P. (1999). Computer interface evaluation using eye movements: methods and constructs. International Journal of Industrial Ergonomics, 24(6), 631-645. http://dx.doi.org/10.1016/S0169-8141(98)00068-7.

Kendel, E., Schwartz, J., \& Jessel, T. (1997). Fundamentos da neurociência e comportamento. Rio de Janeiro: Guanabara Koogan.

Klatzky, R. L. (1998). Allocentric and egocentric spatial representations: definitions, distinctions and interconnections. In C. Freksa, C. Habel \& Wender K. F. (Eds.), Spatial cognition. lecture notes in computer science (Vol. 1404). Berlin, Heidelberg: Springer. http://dx.doi.org/10.1007/3-540-69342-4_1.

Klatzky, R. L., \& Lenderman, S. J. (2009). Object recognition by touch. In J. J. Rieser, D. Ashmead, F. Ebner, \& A. Corn (Eds.). Blindness and brain plasticity in navigation and object perception (p. 185-207). Mahwah, NJ: Erlbaum.

Kunzler, L. S. Q. (2003). Estudo das variáveis de rugosidade, dureza e condutividade térmica aplicado à percepção tátil (Dissertação de mestrado). Universidade Federal do Rio Grande do Sul, Porto Alegre.

Lacey, S., Campbell, C., \& Sathian, K. (2007). Vision and touch: multiple or multisensory representations of objects? Perception, 36(10), 1513-1521. http://dx.doi.org/10.1068/p5850. PMid:18265834.

Lederman, S. J., \& Klatzky, R. L. (1987). Hand movements: a window into haptic object recognition. Cognitive Psychology, 19(3), 342-368. http://dx.doi.org/10.1016/00100285(87)90008-9. PMid:3608405. 
Legge, G. E., Madison, C., Vaughn, B. N., Cheong, A. M., \& Miller, J. C. (2008). Retention of high tactile acuity throughout the life span in blindness. Perception \& Psychophysics, 70(8), 1471-1488. http://dx.doi.org/10.3758/PP.70.8.1471. PMid:19064491.

Loch, R. E. N. (2008). Cartografia tátil: mapas para deficientes visuais. Portal da Cartografia, 1(1), 35-58.

Maillet, B., Guenand, A., \& Lenay, C. (2006). An experimental work on tactile interaction: how to give to the user the possibility to adopt an engaged or a receptive attitude? In Conference on Design and Emotion. Gothenburg: Chalmers University of Technology.

Martins, R. F., \& Merino, E. A. D. (2011). Gestão do design como estratégia organizacional. Londrina: EDUEL.

Mattar, F. B. (2001). Pesquisa de marketing. São Paulo: Atlas.

Meira, P. R. (2005). Comportamento do cliente: princípios teóricos e recentes pesquisas na área. Pelotas: EDUCAT.

Merton, R. K., Fiske, M., \& Kendall, P. L. (1990). The focused interview: a manual of problems and procedures. New York: Free Press.

Montagu, A. (1988). Tocar, o significado humano da pele. São Paulo: Summus.

Munari, B. (1998). Das coisas nascem coisas. São Paulo: Martins Fontes.

Niemeyer, L. (2006). Design atitudinal: uma abordagem projetual. In G. C. Lima (Eds.), Textos selecionados de design. Rio de Janeiro: PPDESDI UERJ.

Okamoto, J. (2002). Percepção ambiental e comportamento: visão holística da percepção ambiental na arquitetura e na comunicação. São Paulo: Mackenzie.

Plaza, J. (2003). Tradução intersemiótica. São Paulo: Perspectiva.

Schimid, A. L. (2005). A ideia de conforto: reflexões sobre o ambiente construído. Curitiba: Pacto Ambiental.

Schoernardie, R. P. (2013). A percepção multissensorial da ergonomia por meio do design de artefatos (Dissertação de mestrado). Universidade do Estado de Santa Catarina, Florianópolis.

Tedeschi, P. (1968). A gênese da forma do desenho industrial. São Paulo: Nobel.

Tullis, T., \& Albert, B. (2008). Measuring the user experience: collecting, analyzing and presenting usability metrics. USA: Elsevier Inc.

Veiga, L., \& Gondim, S. M. G. (2001). A utilização de métodos qualitativos na ciência política e no marketing politico. Opinião Pública, 7(1), 1-15. http://dx.doi.org/10.1590/S010462762001000100001.

Vergara, M., Mondragón, S., Sancho-Bru, J. L., Company, P., \& Agost, M.-J. (2011). Perception of products by progressive multisensory integration: A study on hammers. Applied Ergonomics, 42(5), 652-664. http://dx.doi.org/10.1016/j.apergo.2010.09.014 PMid:21035107.

Voss, C., Tsikriktsis, N., \& Frohlich, M. (2002). Case research in operations management. International Journal of Operations \& Production Management, 22(2), 195-219. http://dx.doi.org/10.1108/01443570210414329.

Yin, R. K. (2001). Estudo de caso: planejamento e método (2a ed.). São Paulo: Bookman. 